\title{
TRACE METAL CONCENTRATIONS IN MARINE ZOOPLANKTON FROM THE WESTERN BAY OF BENGAL
}

\author{
G. REJOMON* - K.K. BALACHANDRAN - M. NAIR - T. JOSEPH \\ National Institute of Oceanography \\ Regional Centre, Kochi-18, India \\ e-mail:rejomon2002@yahoo.co.uk \\ (Received $27^{\text {th }}$ February 2007; accepted $12^{\text {th }}$ August 2007)
}

\begin{abstract}
Trace metal contents in zooplankton samples were estimated as a part of Marine ResearchLiving Resource Programme (MRLR) programme at 24 stations to establish the importance of these metals in the Bay of Bengal. The average concentration of $\mathrm{Fe}, \mathrm{Co}, \mathrm{Ni}, \mathrm{Cu}, \mathrm{Zn}, \mathrm{Cd}$ and $\mathrm{Pb}$ in zooplankton from the Bay of Bengal indicates that it is slightly enriched in coastal samples than offshore samples. The heavy river discharge in the east coast of India might be related to the increased metal bioavailabilities in seawater and hence an increased uptake of metals by zooplankton from coastal areas than offshore areas. The zooplankton species examined showed great accumulations of metals, with bioaccumulation factors in the range $>15,000$ to $40,000,000$ with respect to the concentrations (soluble fractions) in marine waters. Metal concentrations recorded in the Bay of Bengal zooplankton may be used as background levels for future studies, a body of water about which information is still very scarce.
\end{abstract}

Keywords: Bay of Bengal, zooplankton, trace metals, bioaccumulation

\section{Introduction}

The mechanisms of biochemical interactions among trace metals and planktonic organisms is one the keys to elucidate the role of trace metals in the ecology of the oceans and the role of organisms in the bioaccumulation of metals. Trace element accumulation in aquatic consumers is of interest to ecologists and environmentalists so as to understand the fate and effects of contaminants in the food web dynamics as well as in the biogeochemical cycling of trace elements.

Zooplanktons are the most abundant animals in the sea, which play an important role in the marine food chain. They mostly feed on phytoplankton and in turn form food for animals at higher trophic level [7]. Thus, zooplankton may contribute to the transfer of trace metals to higher trophic levels and have been chosen as one of the recommended groups for the base line studies of metals in the marine environment. Natural and anthropogenic metal inputs influence the bioavailable metal supply in aquatic systems. In assessing environmental quality with respect to trace metals in seawater, the bioavailable fraction of trace metals is of major importance, because toxicity depends on bioavailable exposure concentration. This bioavailable fraction cannot be detected directly by measuring metal concentrations, in the soluble phase and can be assessed by determining the amount of metal incorporated into organisms. So far very little work has been done on the trace metal estimation in zooplankton from the Bay of Bengal and the adjoining areas [4,5].

Along the East Coast of India, several large rivers (Fig. 1), open into the coastal waters contributing to the trace metal load of terrestrial and anthropogenic origin [10]. The trace metals in surface seawater and zooplankton were investigated to get an idea of the extent of accumulation of them in zooplankton and the concentration in the sea. 


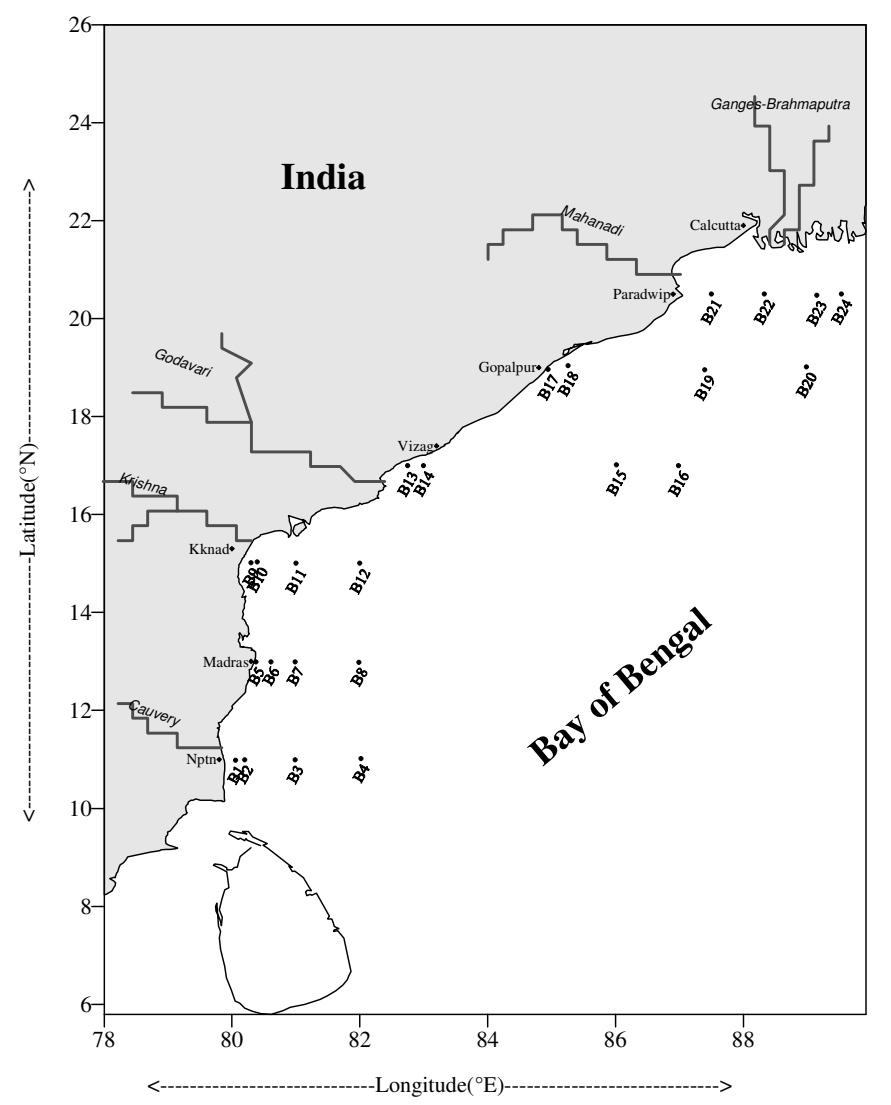

Figure 1. Map of the study area with station locations.

\section{Materials and methods}

As part of Marine Research-Living Resource Programme (MRLR), trace metal distribution in surface seawater and zooplankton were studied in the Indian Exclusive Economic Zone (EEZ) of the Bay of Bengal. The investigation in the Bay of Bengal (Cruise No. 209, November 2002), is based on the samples (Fig. 1), along six transects perpendicular to the coast at $11^{\circ} \mathrm{N}, 13^{\circ} \mathrm{N}, 15^{\circ} \mathrm{N}, 17^{\circ} \mathrm{N}, 19^{\circ} \mathrm{N}$ and $20.5^{\circ} \mathrm{N}$. Trace metal studies were performed in all transects at two coastal $(50 \mathrm{~m}$ depth, inner shelf and $150 \mathrm{~m}$ depth, outer shelf) \& at two offshore stations (> 1000m depth). Seawater and zooplankton samples were collected from surface of each transect in the case of inner shelf, outer shelf and offshore stations. Zooplankton samples were sampled using a Bongo net (mouth area $0.28 \mathrm{~m} 2$, mesh width $300 \mu \mathrm{m}$ ). Zooplankton thus collected were subjected to close visual observation, under a binocular microscope to ensure the absence of any foreign particles and sorted. The composition of zooplankton samples from all the stations showed that copepods were the most dominant in all the samples. Chaetognaths were next in abundance-followed by ostracods and euphausids. Due to different potential for the accumulation of metals in copepods, ostracods and euphasids the sample is sorted and only mixed copepods (zooplankton) are used for the estimation of metals. The zooplankton samples (mixed copepods) were placed in a small nylon sieve and thoroughly rinsed with Milli-Q Water to remove salts. Water adhering to the samples was removed by placing the sieve on good quality filter paper, without any 
contamination. Subsequently, the samples were dried in an oven at $65^{\circ} \mathrm{C}$ and stored in a vacuum desiccator.

Water samples were collected using a PVC-coated new stainless steel CTD-rosette sampler with precleaned 5-litre Teflon coated Go-Flo bottles (General Oceanics). Upon recovery, samples were filtered directly from the Go-Flo samplers, under nitrogen pressure, through preweighed and acid washed $0.45 \mu \mathrm{m}$ membrane (Millipore) filters mounted on Teflon filter blocks to separate them into dissolved and particulate fractions. The filtered water samples were stored after acidifying with pure $\mathrm{HCl}$ to $\mathrm{pH}$ 2-3. Trace metals ( $\mathrm{Fe}, \mathrm{Co}, \mathrm{Ni}, \mathrm{Cu}, \mathrm{Zn}, \mathrm{Cd}$ and $\mathrm{Pb}$ ) in water, using Ammonium Pyrrolidene Dithio Carbamate-Methyl Isobutyl Ketone (APDC-MIBK) extraction [2], were analysed by Graphite Furnace Atomic Absorption Spectrophotometer (GFAAS, ZL-4110). The procedure of dissolved metal was tested using the estuarine water reference material-St. Lawrence Estuarine Water $(\mathrm{SLEW}-2),(\mathrm{n}=5)$ from the National Research Council of Canada (NRC), to check the analytical quality.

Zooplankton samples were first powdered and aliquots of about 300mg were digested for 3 hours at $80^{\circ} \mathrm{C}$ with $300 \mu \mathrm{l} \mathrm{HNO} 3$ (65\%, suprapure, Merck) in tightly closed $2 \mathrm{ml}$ Eppendorf reaction tubes. The digests were made up to $25 \mathrm{ml}$ with $\mathrm{HCl}$ $(0.1 \mathrm{~N})$ and subjected to Flame Atomic Absorption Spectrophotometer (PE A Aanalyst100). The precision and accuracy of analysis was checked by replicate measurements $(n=5)$ of target metals in a standard reference material of marine biota sample-Defated Lobster Tomalley (TORT-2, Lobster Hepatopancreas, National Research Council, Canada). The analysed values obtained for the reference materials of seawater and biota are in excellent agreement with the certified values (Table 1 and 2).

Bioaccumulation factors (concentration factors) were calculated for each metal and organism as the ratio of the metal concentration in the organism's body and its concentration in the ambient water. The bioaccumulation factors for zooplankton were based on dry weights and the same concentration units were used for seawater and zooplankton for its estimation. All metal concentration values in water samples are reported in ppb where as in zooplankton the values reported are in ppm dry weight.

Table 1. Accuracy (given as recovery) and precision (given as standard error) of standard estuarine water (SLEW-2), analysed according to the procedure used for dissolved metal analysis

\begin{tabular}{|c|c|c|c|}
\hline \multirow{2}{*}{ Metal } & \multicolumn{2}{|c|}{$\begin{array}{c}\text { Metal concentration } \\
\text { (ppb } \pm \text { standard error) }\end{array}$} & \multirow{2}{*}{$\begin{array}{c}\text { Recovery } \\
(\%)\end{array}$} \\
\cline { 2 - 3 } & Certified & Measured & \\
\hline $\mathrm{Fe}$ & $2.37 \pm 0.37$ & $2.36 \pm 0.38$ & 99 \\
\hline $\mathrm{Co}$ & $0.055 \pm 0.002$ & $0.056 \pm 0.001$ & 101 \\
\hline $\mathrm{Ni}$ & $0.709 \pm 0.054$ & $0.708 \pm 0.052$ & 99 \\
\hline $\mathrm{Cu}$ & $1.62 \pm 0.11$ & $1.63 \pm 0.10$ & 100 \\
\hline $\mathrm{Zn}$ & $1.10 \pm 0.14$ & $1.11 \pm 0.16$ & 101 \\
\hline $\mathrm{Cd}$ & $0.019 \pm 0.002$ & $0.020 \pm 0.003$ & 105 \\
\hline $\mathrm{Pb}$ & $0.027 \pm 0.005$ & $0.028 \pm 0.004$ & 103 \\
\hline
\end{tabular}


Table 2. Accuracy (given as recovery) and precision (given as standard error) of standard Lobster Hepatopancreas (TORT-2), analysed according to the procedure used for fish metal analysis

\begin{tabular}{|c|c|c|c|}
\hline \multirow{2}{*}{ Metal } & \multicolumn{2}{|c|}{$\begin{array}{c}\text { Metal concentration } \\
\text { (ppm } \pm \text { standard error) }\end{array}$} & \multirow{2}{*}{$\begin{array}{c}\text { Recovery } \\
(\%)\end{array}$} \\
\cline { 2 - 3 } & Certified & Measured & \\
\hline $\mathrm{Fe}$ & $105.0 \pm 13$ & $106.5 \pm 3.13$ & 101 \\
\hline $\mathrm{Co}$ & $0.51 \pm 0.09$ & $0.50 \pm 0.08$ & 98 \\
\hline $\mathrm{Ni}$ & $2.50 \pm 0.20$ & $2.52 \pm 0.22$ & 100 \\
\hline $\mathrm{Cu}$ & $106.0 \pm 10$ & $105.0 \pm 5.03$ & 99 \\
\hline $\mathrm{Zn}$ & $180.0 \pm 6$ & $181.2 \pm 4.78$ & 100 \\
\hline $\mathrm{Cd}$ & $26.7 \pm 0.6$ & $26.9 \pm 0.8$ & 100 \\
\hline $\mathrm{Pb}$ & $0.35 \pm 0.13$ & $0.36 \pm 0.11$ & 102 \\
\hline
\end{tabular}

\section{Results}

Metal concentration data in surface sea water and zooplankton from the Bay of Bengal are compiled in the Tables 3 to 6 . Due to the limited number of independent replicates (represented by one bongo net haul for zooplankton sampling and one CTD cast for water sampling from each station), statistical evaluation of the data (for example employing analysis of variance), is however not applicable. Thus, comparisons between metal concentrations in water and zooplankton species have to be done on a heuristic basis.

The heuristic comparison of the metal concentrations in water and zooplankton from the coastal and offshore sites analysed rely on the ranges, which are compiled in the Tables 3 to 6 . The results vary depending on the area considered. Thus the iron, cobalt, nickel, copper, zinc, cadmium and lead content in water (Table 3), ranged from 0.78 to $3.28 \mathrm{ppb}, 0.032$ to $0.168 \mathrm{ppb}, 0.021$ to $0.124 \mathrm{ppb}, 0.44$ to $1.98 \mathrm{ppb}, 0.92$ to $2.84 \mathrm{ppb}$, 0.012 to $0.048 \mathrm{ppb} \& 0.108$ to $0.723 \mathrm{ppb}$ respectively, whereas in zooplankton (Table 5), it ranged from 1350.2 to $50999.3 \mathrm{ppm}, 14.1$ to $48.8 \mathrm{ppm}, 15.8$ to $66.5 \mathrm{ppm}$, 19.2 to $89.5 \mathrm{ppm}, 174.5$ to $8162.2 \mathrm{ppm}, 8.2$ to $49.4 \mathrm{ppm} \& 1.4$ to $21.1 \mathrm{ppm}$ respectively, at the coastal stations of the Bay of Bengal. Similarly the iron, cobalt, nickel, copper, zinc, cadmium and lead content in water (Table 4), ranged from 1.21 to $2.77 \mathrm{ppb}, 0.008$ to $0.121 \mathrm{ppb}, 0.021$ to $0.081 \mathrm{ppb}, 0.22$ to $1.61 \mathrm{ppb}, 0.78$ to $1.88 \mathrm{ppb}, 0.017$ to $0.035 \mathrm{ppb}$ \& 0.113 to $0.491 \mathrm{ppb}$ respectively, whereas in zooplankton (Table 6), it ranged from 1125.2 to $41512.3 \mathrm{ppm}, 14.1$ to $38.2 \mathrm{ppm}, 15.1$ to $51.3 \mathrm{ppm}, 24.2$ to $74.2 \mathrm{ppm}, 375.4$ to $4233.5 \mathrm{ppm}, 9.2$ to $34.2 \mathrm{ppm} \& 1.5$ to $16.2 \mathrm{ppm}$ respectively, at the offshore stations of the Bay of Bengal.

In general, low trace metal concentrations were found in water and zooplankton from the south end transect of the coastal stations off Nagapatnam $\left(11^{\circ} \mathrm{N}\right)$, except those samples from the coastal stations off Vishakapatnam (Station Positions: B13 \& B14), and followed by off Madras (Station Positions: B5 \& B6), where the levels were high. Further, an offshore enrichment of trace metals were found in water and zooplankton from the open ocean stations off Gopalpur (Station Position: B19), followed by open ocean stations off Vishakapatnam (Station Position: B16), and open ocean stations off Nagapatnam transect (Station Position: B4), where the levels were high. The high 
concentrations of trace metals in zooplankton collected off at coastal as well as offshore stations when compared to other stations might be attributed to their higher concentrations existing in the ambient medium (Table 3 and 4).

Table 3. Dissolved trace metals (ppb) from the coastal stations of the western Bay of Bengal

\begin{tabular}{|c|c|c|c|c|c|c|c|}
\hline $\begin{array}{c}\text { Station } \\
\text { Number }\end{array}$ & $\begin{array}{c}\mathrm{Fe} \\
(\mathrm{ppb})\end{array}$ & $\begin{array}{c}\mathrm{Co} \\
(\mathrm{ppb})\end{array}$ & $\begin{array}{c}\mathrm{Ni} \\
(\mathrm{ppb})\end{array}$ & $\begin{array}{c}\mathrm{Cu} \\
(\mathrm{ppb})\end{array}$ & $\begin{array}{c}\mathrm{Zn} \\
(\mathrm{ppb})\end{array}$ & $\begin{array}{c}\mathrm{Cd} \\
(\mathrm{ppb})\end{array}$ & $\begin{array}{c}\mathrm{Pb} \\
(\mathrm{ppb})\end{array}$ \\
\hline B1 & 0.78 & 0.043 & 0.021 & 0.44 & 1.28 & 0.012 & 0.113 \\
\hline B2 & 0.88 & 0.045 & 0.021 & 0.69 & 1.74 & 0.012 & 0.108 \\
\hline B5 & 2.97 & 0.135 & 0.088 & 1.27 & 2.31 & 0.041 & 0.511 \\
\hline B6 & 2.99 & 0.132 & 0.086 & 1.29 & 2.45 & 0.039 & 0.521 \\
\hline B9 & 2.38 & 0.032 & 0.038 & 0.58 & 1.05 & 0.018 & 0.235 \\
\hline B10 & 2.51 & 0.051 & 0.031 & 0.62 & 1.81 & 0.012 & 0.341 \\
\hline B13 & 3.26 & 0.165 & 0.121 & 1.85 & 2.79 & 0.048 & 0.685 \\
\hline B14 & 3.28 & 0.168 & 0.124 & 1.98 & 2.84 & 0.046 & 0.723 \\
\hline B17 & 2.85 & 0.063 & 0.023 & 1.69 & 0.98 & 0.044 & 0.305 \\
\hline B18 & 2.84 & 0.065 & 0.022 & 1.08 & 0.92 & 0.033 & 0.395 \\
\hline B21 & 2.66 & 0.061 & 0.035 & 1.07 & 1.72 & 0.021 & 0.283 \\
\hline B22 & 2.68 & 0.051 & 0.036 & 1.06 & 1.98 & 0.033 & 0.273 \\
\hline
\end{tabular}

Table 4. Dissolved trace metals (ppb) from the offshore stations of the western Bay of Bengal

\begin{tabular}{|c|c|c|c|c|c|c|c|}
\hline $\begin{array}{c}\text { Station } \\
\text { Number }\end{array}$ & $\begin{array}{c}\mathrm{Fe} \\
(\mathrm{ppb})\end{array}$ & $\begin{array}{c}\mathrm{Co} \\
(\mathrm{ppb})\end{array}$ & $\begin{array}{c}\mathrm{Ni} \\
(\mathrm{ppb})\end{array}$ & $\begin{array}{c}\mathrm{Cu} \\
(\mathrm{ppb})\end{array}$ & $\begin{array}{c}\mathrm{Zn} \\
(\mathrm{ppb})\end{array}$ & $\begin{array}{c}\mathrm{Cd} \\
(\mathrm{ppb})\end{array}$ & $\begin{array}{c}\mathrm{Pb} \\
(\mathrm{ppb})\end{array}$ \\
\hline B3 & 2.21 & 0.102 & 0.035 & 0.22 & 0.98 & 0.015 & 0.115 \\
\hline B4 & 2.71 & 0.121 & 0.062 & 0.89 & 1.01 & 0.021 & 0.491 \\
\hline B7 & 1.21 & 0.008 & 0.034 & 0.62 & 0.78 & 0.017 & 0.143 \\
\hline B8 & 2.02 & 0.008 & 0.021 & 0.56 & 0.78 & 0.018 & 0.156 \\
\hline B11 & 2.59 & 0.084 & 0.023 & 0.65 & 0.98 & 0.018 & 0.385 \\
\hline B12 & 1.29 & 0.078 & 0.032 & 0.52 & 0.98 & 0.021 & 0.113 \\
\hline B15 & 2.51 & 0.045 & 0.061 & 0.58 & 0.98 & 0.021 & 0.188 \\
\hline B16 & 2.77 & 0.111 & 0.081 & 1.61 & 1.88 & 0.035 & 0.348 \\
\hline B19 & 2.75 & 0.121 & 0.071 & 1.03 & 1.21 & 0.034 & 0.488 \\
\hline B20 & 2.72 & 0.045 & 0.032 & 0.59 & 0.95 & 0.021 & 0.172 \\
\hline B23 & 2.51 & 0.108 & 0.061 & 0.54 & 0.98 & 0.019 & 0.145 \\
\hline B24 & 2.51 & 0.112 & 0.061 & 0.54 & 0.98 & 0.019 & 0.145 \\
\hline
\end{tabular}

Table 5. Zooplankton trace metals (ppm) from the coastal stations of the western Bay of Bengal

\begin{tabular}{|c|c|c|c|c|c|c|c|}
\hline $\begin{array}{c}\text { Station } \\
\text { Number }\end{array}$ & $\begin{array}{c}\mathrm{Fe} \\
(\mathrm{ppm})\end{array}$ & $\begin{array}{c}\mathrm{Co} \\
(\mathrm{ppm})\end{array}$ & $\begin{array}{c}\mathrm{Ni} \\
(\mathrm{ppm})\end{array}$ & $\begin{array}{c}\mathrm{Cu} \\
(\mathrm{ppm})\end{array}$ & $\begin{array}{c}\mathrm{Zn} \\
(\mathrm{ppm})\end{array}$ & $\begin{array}{c}\mathrm{Cd} \\
(\mathrm{ppm})\end{array}$ & $\begin{array}{c}\mathrm{Pb} \\
(\mathrm{ppm})\end{array}$ \\
\hline B1 & 1968.1 & 17.2 & 15.8 & 23.3 & 179.3 & 11.2 & 1.4 \\
\hline B2 & 1350.2 & 18.3 & 18.2 & 21.8 & 174.5 & 10.1 & 1.8 \\
\hline B5 & 25437.1 & 38.2 & 55.1 & 75.3 & 5800.3 & 38.1 & 16.5 \\
\hline B6 & 25291.3 & 40.3 & 53.1 & 73.1 & 5889.4 & 36.2 & 12.8 \\
\hline B9 & 5625.1 & 14.1 & 18.1 & 19.2 & 1358.8 & 8.2 & 1.8 \\
\hline B10 & 5569.2 & 14.2 & 21.5 & 22.2 & 1333.6 & 13.3 & 4.4 \\
\hline B13 & 50999.3 & 46.8 & 62.1 & 89.5 & 8162.2 & 48.8 & 21.1 \\
\hline B14 & 50962.1 & 48.8 & 66.5 & 88.2 & 8066.1 & 49.4 & 20.1 \\
\hline B17 & 14200.3 & 18.1 & 38.8 & 42.2 & 1480.2 & 12.2 & 4.9 \\
\hline B18 & 14950.4 & 20.3 & 36.4 & 40.1 & 1483.3 & 12.3 & 5.6 \\
\hline B21 & 3125.1 & 26.1 & 21.1 & 45.1 & 1205.6 & 12.2 & 2.1 \\
\hline B22 & 3925.1 & 17.1 & 18.1 & 56.2 & 1241.1 & 10.2 & 1.9 \\
\hline
\end{tabular}


Table 6. Zooplankton trace metals (ppm) from the offshore stations of the western Bay of Bengal

\begin{tabular}{|c|c|c|c|c|c|c|c|}
\hline $\begin{array}{c}\text { Station } \\
\text { Number }\end{array}$ & $\begin{array}{c}\mathrm{Fe} \\
(\mathrm{ppm})\end{array}$ & $\begin{array}{c}\mathrm{Co} \\
(\mathrm{ppm})\end{array}$ & $\begin{array}{c}\mathrm{Ni} \\
(\mathrm{ppm})\end{array}$ & $\begin{array}{c}\mathrm{Cu} \\
(\mathrm{ppm})\end{array}$ & $\begin{array}{c}\mathrm{Zn} \\
(\mathrm{ppm})\end{array}$ & $\begin{array}{c}\mathrm{Cd} \\
(\mathrm{ppm})\end{array}$ & $\begin{array}{c}\mathrm{Pb} \\
(\mathrm{ppm})\end{array}$ \\
\hline B3 & 1125.2 & 17.2 & 20.1 & 24.2 & 425.8 & 11.8 & 2.2 \\
\hline B4 & 15075.3 & 25.2 & 38.4 & 69.2 & 2666.2 & 25.1 & 4.9 \\
\hline B7 & 3275.3 & 20.4 & 20.3 & 35.3 & 484.2 & 12.2 & 1.9 \\
\hline B8 & 3543.4 & 14.1 & 15.1 & 30.1 & 392.3 & 9.3 & 1.6 \\
\hline B11 & 3106.1 & 22.1 & 30.2 & 27.2 & 375.4 & 15.1 & 1.5 \\
\hline B12 & 3525.2 & 24.3 & 34.4 & 32.1 & 783.3 & 18.3 & 3.5 \\
\hline B15 & 4556.2 & 17.3 & 15.1 & 34.4 & 458.2 & 11.2 & 7.7 \\
\hline B16 & 26212.3 & 38.2 & 51.3 & 74.2 & 3337.1 & 34.2 & 16.2 \\
\hline B19 & 41512.3 & 34.1 & 48.2 & 71.3 & 4233.5 & 26.3 & 15.9 \\
\hline B20 & 12062.3 & 20.1 & 33.3 & 62.3 & 1650.1 & 9.2 & 3.1 \\
\hline B23 & 10631.3 & 21.2 & 30.3 & 39.4 & 1458.1 & 22.3 & 2.8 \\
\hline B24 & 10631.2 & 21.2 & 30.3 & 39.7 & 1666.2 & 24.4 & 2.8 \\
\hline
\end{tabular}

Considering Bay of Bengal background concentrations of metals observed in biota as natural, it is interesting to compare the data regional wise as well as with the reported values from other regions of the world. Thus, the average iron content $(50980.5 \mathrm{ppm})$, in zooplankton and sea water (3.27 ppb), off Vishakapatnam coast showed a thirty-fold and four-fold increase in its concentration respectively, when compared to coastal stations off Nagapatnam transect $\left(11^{\circ} \mathrm{N}\right)$ in the western Bay of Bengal. This is followed by a high average concentration of iron in zooplankton $(25364 \mathrm{ppm})$, and sea water (2.98 ppb), off Madras. Like wise, the average cobalt as well as nickel content in sea water and zooplankton at the coastal stations off Vishakapatnam $(0.167 \mathrm{ppb} \& 47.8$ ppm, $0.123 \mathrm{ppb} \& 64.3 \mathrm{ppm}$ ), and off Madras (0.133 ppb \& $39.3 \mathrm{ppm}, 0.087 \mathrm{ppb} \&$ $54.1 \mathrm{ppm}$ ), showed higher values than the other coastal stations in the Bay of Bengal. Similarly, the coastal stations off Vishakapatnam had higher average values for copper as well as zinc in sea water and zooplankton (1.92 ppb \& 88.8 ppm, $2.82 \mathrm{ppb} \& 8114.2$ ppm), followed by off Madras (1.28 ppb \& $74.2 \mathrm{ppm}, 2.38 \mathrm{ppb} \& 5844.5 \mathrm{ppm}$ ), in the Bay of Bengal. The spatial variations of copper and zinc content in zooplankton at most locations from the coastal as well as offshore waters in the present study agrees well with the reported copper (22 ppm) and zinc (474 ppm) content of mesozooplankton by [14], for the North Sea.

Cadmium values in sea water and in surface zooplankton of the coastal stations off Vishakapatnam (0.047 ppb \& $49.1 \mathrm{ppm})$, and off Madras (0.041 ppb \& $37.2 \mathrm{ppm})$, showed higher values than offshore samples in the respective transects of the western Bay of Bengal. Similar to cadmium, a high average concentration of lead (20.6 ppm) was observed in coastal zooplankton and water $(0.704 \mathrm{ppb})$ respectively samples off Vishakapatnam and was followed by off Madras area for zooplankton (14.7 ppm) and sea water $(0.516 \mathrm{ppb})$. The spatial variations of cadmium content in zooplankton at all locations from the coastal as well as offshore waters in the present study were higher than the reported cadmium (1.9 ppm) content of mesozooplankton by [14], for the North Sea. However, the spatial variations of lead content in zooplankton at most locations from the offshore waters in the present study were lower than the reported lead $(2.4$ ppm) content of mesozooplankton by [14], for the North Sea. 


\section{Discussion}

It is distinctive, from the investigated data set that spatial variation of concentration of metals in zooplankton, increases towards the coastal areas especially at off $17^{\circ} \mathrm{N} \&$ $13^{\circ} \mathrm{N}$ and again with a further increasing trend towards offshore stations of northern $\left(19^{\circ} \mathrm{N} \& 17^{\circ} \mathrm{N}\right)$ as well as southern latitudes $\left(11^{\circ} \mathrm{N}\right)$. This is very often coincided by the increased concentrations of dissolved metals in the coastal and offshore areas, which in turn indicates the usefulness of zooplankton as a bioindicator [9].

The coastal and offshore enrichment of trace metals in zooplankton may be attributed to the peculiar hydrology and gyral circulation pattern of the Bay of Bengal. The Bay of Bengal has an extensive coastal zone as well as deep basins with different water masses and receives massive freshwater inputs from nearby rivers to the coastal zone. The northern shelf of the Bay of Bengal gets strongly affected by the entrainment of increased loads of fresh waters during summer and winter, originating from the GangesBrahamaputra, Mahanadi and Godavari riverine systems in the north which in turn drops the salinity gradient to $>8.0 \mathrm{psu}$ in the nearby coastal zones [8]. The impact of such a huge influx of freshwater discharge results the Bay of Bengal as a trap for trace metals especially in the coastal zone as evident conspicuously from the peaking up of metal content in water and zooplankton at the coastal stations off Vishakapatnam and off Madras from the extensive coastal area investigated.

The riverine input of dissolved metals are coastally trapped by eddies and also since shelf areas are under a directive influence of increased loads of trace metals from terrestrial sources relative to oceanic waters, it results in an average higher value for all the metals in coastal zooplankton samples than from offshore samples (Table $7 \& 8$ ), in the Bay of Bengal $[6,8]$. Moreover a significant quantity of sediments impregnated with trace metals are also supplied by major rivers along the east coast of India and were constantly moved by coastally trapped waves either towards north or south depending on the direction and angle of wave approach with respect to the coast also results in a net accumulation of metals in coastal zooplankton from the Bay of Bengal [10].

The offshore enrichment of trace metals in water and zooplankton from the open ocean stations at off Gopalpur, off Vishakapatnam and off Nagapatnam transects, seems to be related to the southerly flowing East India Coastal Current (EICC) from the head of the Bay of Bengal and the peculiar gyral circulation pattern of the Bay of Bengal during the period [11, 13]. The low saline Bay of Bengal waters with moderate dissolved metal concentrations is of riverine origin coming from the northern portion of the system, probably draining from the huge Ganges-Brahamaputra, Mahanadi and Godavari rivers and mixes with the eddies as it flow southwards by EICC with a moderately saline and with low metal concentration as observed in the southern tip of the shelf areas [8]. Fresh and new river waters with high metal contents enter the system from the north continuously during heavy runoff and mix with the already modified water mass by eddies moving southwards. Under the influence of these gyres and as a consequence of the geometry of the East Coast of India (U-shaped basin), the low saline waters of riverine origin with moderate dissolved metal concentrations in the shelf regions, drifts offshore by the simultaneous prevalence of anticlockwise surface currents, and dissolved metals are trapped within the cold-core eddies thereby favouring significant accumulation of trace metals in zooplankton from the offshore areas [12].

The observed regional wise high dissolved metal concentration levels in sea water results from a high riverine influx of metals from the neighbouring hinterlands. These metals are transported from the adjacent land masses by a subsequent leaching from 
enriched soils due to heavy rainfall and the associated floods to the neighbouring rivers, which in turn finds a direct way to the upper ocean surface principally through the heavy surface runoff and in turn accommodated in the seawater by the drifting gyres in different directions. These drifting gyres in turn may play a role in keeping a major population of zooplankton organisms in a given region by taking advantage of the interfaces between different water bodies in spite of the movements of the water. Thus for a given water body, zooplankton exhibits mostly diurnal vertical migration irrespective of water movements to such an extent that they spend most of their time for swimming up or down only as it is evidenced by its high concentration within the whole bodies from the coastal and offshore regions due the subsequent uptake of the dissolved metal by zooplankton [1].

The average concentration of trace metals in zooplankton, from the coastal as well as offshore waters of the Bay of Bengal (Table $7 \& 8$ ), showed a same sequence as follows: $\mathrm{Fe}>\mathrm{Zn}>\mathrm{Cu}>\mathrm{Ni}>\mathrm{Co}>\mathrm{Cd}>\mathrm{Pb}$. All the elements showed a relative enrichment in zooplankton from the coastal waters than from the offshore waters in the Bay of Bengal (Table $7 \& 8$ ). The element iron and zinc showed a two fold increase in its concentration from the coastal waters when compared to the concentration of iron and zinc in zooplankton from the offshore waters of the Bay of Bengal. Likewise, the elements like cobalt, nickel, copper, cadmium and lead were slightly enriched (1.2 to 1.5 times) in zooplankton from the coastal waters when compared to zooplankton samples taken from the offshore waters of the Bay of Bengal.

Table 7. Average concentration of trace metals in different compartments and average bioaccumulation (baf) factors for trace metals in zooplankton from the coastal stations of the western Bay of Bengal

\begin{tabular}{|c|c|c|c|c|c|c|c|}
\hline Metal & $\mathrm{Fe}$ & $\mathrm{Co}$ & $\mathrm{Ni}$ & $\mathrm{Cu}$ & $\mathrm{Zn}$ & $\mathrm{Cd}$ & $\mathrm{Pb}$ \\
\hline $\begin{array}{c}\text { Dissolved } \\
\text { (ppb) }\end{array}$ & 2.51 & 0.084 & 0.054 & 1.13 & 1.82 & 0.029 & 0.375 \\
\hline $\begin{array}{c}\text { Zooplankton } \\
\text { (ppm) }\end{array}$ & 20008.2 & 26.6 & 35.4 & 49.7 & 3031.4 & 21.9 & 7.8 \\
\hline $\begin{array}{c}\text { Bioaccumulati } \\
\text { on factors } \\
\text { (baf) }\end{array}$ & 5810877.8 & 342400.9 & 794095.2 & 43300.7 & 1450181.7 & 738002.7 & 17475.3 \\
\hline
\end{tabular}

Table 8. Average concentration of trace metals in different compartments and average bioaccumulation (baf) factors for trace metals in zooplankton from the offshore stations of the western Bay of Bengal

\begin{tabular}{|c|c|c|c|c|c|c|c|}
\hline Metal & $\mathrm{Fe}$ & $\mathrm{Co}$ & $\mathrm{Ni}$ & $\mathrm{Cu}$ & $\mathrm{Zn}$ & $\mathrm{Cd}$ & $\mathrm{Pb}$ \\
\hline $\begin{array}{c}\text { Dissolved } \\
\text { (ppb) }\end{array}$ & 2.32 & 0.078 & 0.047 & 0.69 & 1.04 & 0.021 & 0.241 \\
\hline $\begin{array}{c}\text { Zooplankton } \\
\text { (ppm) }\end{array}$ & 11227.4 & 22.9 & 30.6 & 44.8 & 1494.5 & 18.2 & 5.3 \\
\hline $\begin{array}{c}\text { Bioaccumulat } \\
\text { ion factors } \\
\text { (baf) }\end{array}$ & 4478691.4 & 592223.4 & 707634.5 & 69059.2 & 1337228.2 & 842210.9 & 22039.2 \\
\hline
\end{tabular}


Since bioaccumulation factors represent the potential of organisms to bioaccumulate metals, a comparative ranking of bioaccumulation factors is of great interest. The bioaccumulation factor is evaluated in relation to the concentration of the soluble metal ion in which the zooplankton inhabits. The data shown in Table $7 \& 8$ confirm the high aptitude of the zooplankton as bioaccumulators of metals. The average bioaccumulation factor of elements in zooplankton from the coastal waters (Table 7), followed an order: $\mathrm{Fe}>\mathrm{Zn}>\mathrm{Ni}>\mathrm{Cd}>\mathrm{Co}>\mathrm{Cu}>\mathrm{Pb}$, whereas in offshore waters (Table 8), it followed an order: $\mathrm{Fe}>\mathrm{Zn}>\mathrm{Cd}>\mathrm{Ni}>\mathrm{Co}>\mathrm{Cu}>\mathrm{Pb}$, in the Bay of Bengal. The bioaccumulation factors for all metals followed the same order except for $\mathrm{Cd}$ and $\mathrm{Ni}$ probably due to variations in the passage of these metals through the trophic food chain in coastal as well as offshore waters.

The observed relative enrichment of metals in zooplankton from coastal waters when compared with offshore waters points to the importance of bioavailability of metals in seawater as well as regional differences in the potential of trace metal accumulation in zooplankton organisms from the Bay of Bengal. The relative enrichment of metals in zooplankton from the coastal waters than from offshore waters may be possibly either related to changing accumulation strategies of the copepod species involved or to changing bioavailabilities of metals in the seawater due to the influence of local river discharge as well as physical forcings such as eddies. The possibility of changing accumulation strategies of the copepod species involved can be ruled out, since the surface samples are collected from the coastal and offshore waters and the composition of the species involved will not vary appreciably. Thus, it is worth noting that, local river discharge in the east coast of India, might be related to the increased metal bioavailabilities in seawater and hence increased uptake of metals into zooplankton from coastal areas than offshore areas. Moreover, it is obvious that metals may be available for uptake by biota in a more bioavailable form in coastal waters than offshore waters since bioavailability of metals may alter with environmental factors such as salinity, temperature, dissolved organic compounds as well as food supply [3].

From this study, it is clear that the sequence of metal content for all elements will not vary for both the coastal and offshore Bay of Bengal zooplankton. Further, a comparison of bioaccumulation of metals in zooplankton from the coastal and offshore waters of the Bay of Bengal reveals that iron is bioaccumulated more than any other metal; zinc, nickel and cadmium showed a similar enrichment and least for lead.

\section{Conclusion}

The zooplankton examined showed a great ability to accumulate concentrations of metals several thousand times than those detected in marine water (soluble fraction). From this study, it is worthwhile to remark that, there is a need for a better understanding of background information on trace metal concentrations with respect to space and time and their fluctuations in the Bay of Bengal zooplankton. Without a sound knowledge on spatio-temporal fluctuations, it will be impossible to differentiate anthropogenic metal inputs from natural background concentrations with a routine biomonitoring programme. Although the zooplankton species studied in the present work and suggested as biomonitors present numerous advantages, more information and more studies are necessary to clarify accumulation patterns. Nevertheless this study can be looked upon as a starting point for further investigations on these processes. 
Acknowledgements. We are grateful to the director, National Institute of Oceanography, Goa for providing facilities for the study. We thank Department of Ocean Development, New Delhi for the financial support to the Marine Research - Living Resources (MR-LR) Assessment programme funded by Centre for Marine Living Resources and Ecology (CMLRE), Kochi. This is a NIO contribution.

\section{REFERENCES}

[1] Bainbridge, R. (1953): Studies on the interrelationships of zooplankton and phytoplankton. - Journal of Marine Biological Association U.K 32: 375-445.

[2] Brooks, R.R., Presley, B.J., Kaplan, I.R. (1967): APDC-MIBK extraction system for the determination of trace elements in saline waters by Atomic Absorption Spectrophotometry. - Talata 14: 809-816.

[3] Brown, M., Depledge, M. (1991): Determinations of trace metal concentrations in marine organisms. - In: Langston, W., Bebianno, M. (Eds.), Metal Metabolism in Aquatic Environments. Chapman and Hall, London, pp. 185-217.

[4] Gajbhiye, S.N., Vijayalakshmi, R.N., Narvekar, P.V., Desai, B.N. (1985): Concentration and Toxicity of some metals in zooplankton from near shore waters of Bombay. - Indian Journal of Marine Sciences 14: 181-183.

[5] George, M.D., Kureishy, T.W. (1979): Trace metals in zooplankton from the Bay of Bengal. - Indian Journal of Marine Sciences 8: 190-192.

[6] Hydes, D.J., Kremling, K. (1993): Patchiness in dissolved metals in North Sea surface waters: Seasonal differences and influence of suspended sediment. - Continental Shelf Research 13: 1083-1101.

[7] Kleppel, G.S. (1993): On the diets of calanoid copepods. - Marine Ecology Progress Series 99: 183-195.

[8] Prasanna Kumar, S., Nuncio, M., Jayu Narvekar. (2004): Are eddies nature's trigger to enhance biological productivity in the Bay of Bengal? - Geophysical Research Letters 31: L 07309, doi: 10.1029/2003 GL019274.

[9] Rainbow, P.S. (1993): The significance of trace metal concentration in marine invertebrates. - In: Dallinger, R., Rainbow, P.S. (Eds.), Ecotoxicology of metals in invertebrates. Lewis Publishers, Boca Raton, USA: 04-23 pp.

[10] Rengasamy, A., Jing, Z. (2005): Comparative studies on trace metal geochemistry in Indian and Chinese rivers. - Current Science 89: 299-309.

[11] Shankar, D., Vinayachandran, P.N., Unnikrishnan, A.S. (2002): The monsoon currents in the north Indian Ocean. - Progress in Oceanography 52: 63-120.

[12] Shetye, S.R., Gouveia, A.D., Shankar, D., Shenoi, S.S.C., Vinayachandran, P., Sundar, D., Michael, G.S., Namboodiri, G. (1996): Hydrography and circulation in the western Bay of Bengal during northeast monsoon. - Journal of Geophysical Research 101: 1401114025.

[13] Suryanarayana, A., Murty, V.S.N., Rao, D.P. (1993): Hydrography and circulation of the Bay of Bengal during early winter. - Deep-Sea Research 40: 205-217.

[14] Zauke, G. P, Krause, M., Weber, A. (1996): Trace metals in mesozooplankton of the North Sea: Concentrations in different taxa and preliminary results on bioaccumulation in copepod collectives (Calanus finmarchicus/C. helgolandicus). - Int Revue Ges Hydrobiol 81: 141-160. 